\section{Self-rated health by HIV-infected individuals undergoing antiretroviral therapy in Brazil}

\author{
Autoavaliação do estado de saúde por indivíduos \\ infectados pelo HIV em terapia antirretroviral \\ no Brasil
}

\author{
1 Instituto de Comunicação \\ e Informação Científica \\ e Tecnológica em Saúde, \\ Fundação Oswaldo Cruz, \\ Rio de Janeiro, Brasil. \\ 2 Faculdade de Medicina, \\ Universidade de São Paulo, \\ São Paulo, Brasil. \\ Correspondence \\ P. R. B. Souza Junior \\ Instituto de Comunicação \\ e Informação Científica \\ e Tecnológica em Saúde, \\ Fundação Oswaldo Cruz. \\ Av. Brasil 4365, Pavilhão \\ Haity Moussatché, sala 225, \\ Rio de Janeiro, $R J$ \\ 21040-900, Brazil. \\ pborges@cict.fiocruz.br
}

\begin{abstract}
In 2008, a survey was applied to a probabilistically selected sample of 1,245 HIV-infected patients on antiretroviral therapy in Brazil. In this work, the analysis was focused on self-rated health. The analysis was conducted according to sex, age, socioeconomic variables, and clinical and treatment-related patient characteristics. Through stepwise logistic regression procedures, the main predictors of good perception of health status were established. Results showed that 65\% self-rated health state as good or excellent, $81 \%$ do have no or slight difficulty in following treatment, but $34 \%$ men and $47 \%$ women reported intense or extreme degree of anxiety/worry feelings. Educational level, work situation, presence of side effects and AIDS-related symptoms were the main predictors of good self-perception of health. Problems related to animus status, involving worry and anxiety about the future are still barriers that must be overcome to improve quality of life of people living with HIVIAIDS.
\end{abstract}

Highly Active Antiretroviral Therapy; HIV; SelfAssessment; Affect
Paulo Roberto Borges de Souza Junior 1

Célia Landmann Szwarcwald 1

Euclides Ayres de Castilho 2

\section{Introduction}

The self-rated health is a measure that has been widely employed in epidemiological surveys to describe the health status of a population 1 . It is considered a useful and easily measured indicator, which has been used to establish differences in morbidity in population subgroups, compare needs for health services and resources by geographic area and to calculate other indicators of morbidity and mortality such as the healthy life expectancy 2,3 .

Personal perception of health status has been considered an important indicator by itself, since an individual's well-being can affect motivation and quality of life. On the other hand, self-evaluations are also useful due to their validity, established in relation to clinical status and morbidity and mortality indicators 4,5 .

Studies have shown that the individual perception of health frequently agrees with medical evaluation ${ }^{6}$. In terms of mortality, since 1982, when researchers first proved the association between poor self-assessment of health status and increased risk of death among the elderly 7 , several studies have shown that poor self-rated health is an important indicator of reduced survival 8,9,10.

While an objective health evaluation from a medical point of view seeks to identify disease, as indicated by a set of signs, symptoms and laboratory tests, self-evaluations are subjective, com- 
bining aspects of physical and emotional wellbeing and satisfaction with life. Self-perception of health status refers not just to feelings of pain and discomfort, but also to the psychological and social consequences of having a health problem ${ }^{11}$.

The quality of life of people living with HIV/ AIDS has improved considerably with the advent of antiretroviral therapy (ART), especially highly active antiretroviral therapy (HAART), a treatment which is expected to reduce viral load to less than 50 copies $/ \mathrm{mL}$ of blood in patients virgin to treatment 12,13.

The universal access to ART in Brazil since 1996 has resulted in an increase of survival and a significant reduction in hospitalizations 14,15. Chequer et al. 16 estimated a median survival of 5.1 months for adult patients from 1982 to 1989 , while Marins et al. 15 estimated a median survival of 18 months for adult patients diagnosed in 1995, and 58 months for patients diagnosed in 1996, with ART being significantly associated with the survival increase. In a study carried out among patients diagnosed between 1998 and 1999 in the South and Southeast regions in Brazil, the median survival rate could not be estimated in 9 years of observation as $59 \%$ of patients have survived for 108 months 17.

According to data provided by the Department of STD, AIDS and Viral Hepatitis Monitoring System (http://sistemas.aids.gov.br/monitoraids), the rate of hospitalizations per AIDS patients under ART reduced from 0.63 in 1998 to 0.13 in 2008. However, little is known about the quality of life of AIDS patients under ART, nor about changes in living and working conditions resulting from the disease.

In the year of 2008, the Department of STD, AIDS and Viral Hepatitis, with the financial support from the United States Agency for International Development (USAID), developed a health survey among patients under ART to analyze the health system responsiveness according to their needs and the quality of life of AIDS patients. In respect to quality of life, with the understanding that self-rated health is a measure that includes not just physical aspects but also well-being and life satisfaction 11, a module designed to evaluate self-perception of health in its various dimensions was included in the survey as one of the study topics. The aim of this study was to analyze the self-rated health and its association with sex, age, socioeconomic status and characteristics related to the treatment among AIDS patients receiving ART in Brazil.

\section{Methodology}

In 2008, a survey was performed in a probabilistically selected sample of people infected by HIV under ART, with the purpose of evaluating the quality of life and the performance of the health system from the user's perspective. The project was approved by the Ethics Committee of the Sergio Arouca National School of Public Health, Oswaldo Cruz Foundation (CAAE: 0142.0.031.031-07).

The sample size was calculated to estimate the proportion of patients under ART who consider their quality of life as moderate or good. In an Australian study, 35\% of people living with HIV/AIDS under the age of 50 reported adverse health conditions ${ }^{18}$. Using this estimate as a base for calculating the sample size, considering a $95 \%$ confidence interval with a $3 \%$ bilateral margin of error, a minimum number of 971 subjects was obtained. As the sample was selected in two stages, a design effect of 1.3 was considered, and a final sample size of 1,260 patients was obtained.

The sampling was carried out in two selection stages. In the first stage, 42 antiretroviral drug dispensing units (ADDU) were selected, using a probability proportional to their size, according to the number of registered patients on lists provided by the Department of STD, AIDS and Viral Hepatitis. Given the study timeframe, only ADDU with at least 200 registered patients were considered eligible for selection. However, this eligibility criterion did not affect the selection of a representative sample, since eligible units comprehend $90.6 \%$ of registered patients.

In the second stage, 30 patients were randomly selected from each of the chosen ADDU during fieldwork, from the list of patients scheduled in the study period.

The patients answered a modular questionnaire, which included the following modules: socio-demographic, residence and patient characteristics, self-rated health status, health system performance, and quality of life.

The modules addressing health system performance and self-rated health status were based on aWorld Health Organization (WHO) questionnaire used in the World Health Survey, applied in Brazil in 2003 (http://www.who.int/healthinfo/ survey/en) 19,20, and the modules addressing quality of life were based on the WHO survey designed for this purpose (available at http:// www.who.int/mental_health/media/en/557.pdf - original version - or http://www.ufrgs.br/psiq/ whoqol_hiv_03.pdf - Portuguese version) 21,22. The module on self-rated health status is the focus of the current study. 
The interviews were performed face to face, whenever possible in a private room provided by the health unit. In the case of unavailability of a private room, the interviewers were advised to search for privacy, in a place away from the waiting room to conduct the interview. The average interview time was 20 minutes and handheld computers were used for the data collection.

Analysis of self-rated health was based on the following question: "In general, how do you currently rate your health?”. The responses were ranked on a scale from 1 to 5 ( $1=$ excellent; $2=$ good; 3 = moderate; 4 = bad; 5 = very bad). Two additional questions were included with the same ranking scale: "In general, how do you rate your ability to work?" and "In general, how do you rate your physical appearance?".

Regarding the dimensions of health status, questions were included about the degree of difficulty involved in: carrying out day-to-day activities; locomotion; dressing and self-care; personal relationships; concentration or memory; sleeping well and disposition. Questions were also asked about the degree of pain or bodily discomfort experienced, and about feelings of sadness or depression and anxiety or worry. All of the questions referred to the previous 30 days, with a ranking scale from 1 to 5 , from the better to the worst evaluation.

Analysis was conducted according to sex, age (18-49 vs. $50+$ years old), socio-economic status, and clinical and treatment-related characteristics of patients. To examine inequalities by socio-economic status, three variables were considered: schooling, monthly income, and economic class, as defined by the Brazilian Economic Classification Criteria 23, which uses information about household goods and the head of household's level of schooling. Among the patient characteristics evaluated were: category of exposure; presence of symptoms related to AIDS; most recent CD4+ count; year of beginning ART; presence of side effects, including lipodystrophy.

For the multivariate analyses, logistic regression models were used, with the self-rated health as the response variable $(1=$ good or excellent; $0=$ moderate, bad or very bad). Through stepwise procedures, the main predictors of good self-perception of health status were established.

SPSS version 15 (SPSS Inc., Chicago, USA) was used for statistical analysis, taking into account the sample design.

At last, the self-rated health indicators of AIDS patients were compared with those obtained for the Brazilian population by the World Health Survey 19 , considering common questions to both surveys.

\section{Results}

We analyzed 1,245 patients receiving ART at public health facilities throughout the country. Fiftynine percent were male and $41 \%$ were female (Table 1). Age varied from 19 to 72 years, with mean and median values of 41 years. Distribution by age group was equal for both sexes, with $79 \%$ between 15 and 49 years and $21 \%$ age 50 or over. Among patients 50 years old or over, $68.5 \%$ started ART prior to 2003.

The results by educational level showed that: $44 \%$ did not complete fundamental school (3\% are illiterate); $20 \%$ had completed primary school; 28\% had completed secondary school; and $8 \%$ had college degree. The proportion of patients who have completed at least primary education was $56 \%$, with $60 \%$ among men and $50 \%$ among women, according to Table 1.

Regarding the marital status, $44.7 \%$ of the male patients have never been married and $34.7 \%$ are married or live with a partner. Among the women, $18.6 \%$ of them have never been married. Regarding skin color, $46.2 \%$ defined themselves as white, $39 \%$ as brown and $13 \%$ as black (Table 1).

Regarding the work status (Table 1), in total $58 \%$ of cases was not working at the time of the survey (55\% among men and $62 \%$ among women). Among men, disease retirement (31.3\%), disability (14.7\%), and to receive disease benefits (24.6\%) were the main reasons for not working. Among women, 28\% were housewives, $15.4 \%$ were retired, $11 \%$ were disabled, and $15.4 \%$ received disease benefits (Table 1 ).

The distribution of patients by income group shows that $18 \%$ have no income $(13.5 \%$ of the men and $24.1 \%$ of the women); almost $50 \%$ earn less than twice the minimum wage; and only $7 \%$ have monthly income greater than $\mathrm{R} \$ 2,000.00$ (Table 1).

According to the Brazilian Economic Classification Criteria $23,53 \%$ of the patients belong to class "C" and $28 \%$ to classes "D" or "E".

The characteristics of the patients by sex are presented in Table 2. Almost 30\% of the patients started ART between 2000 and 2003 and 19\% began treatment in the past two years (2007-2008). Sixty-five patients $(6 \%)$ started treatment before 1996 , prior to the onset of universal anti-retrovirus distribution. Most patients (88\%) were infected through sexual contact and among men, $47 \%$ via heterosexual contact, and $38 \%$ via homosexual contact. About $56 \%$ present symptoms of AIDS, with a slightly higher proportion amongst the men, although the difference was not statistically significant. Among patients who responded to the question about most recent CD4+ counts, 
Socio-demographic characteristics of patients receiving antiretroviral therapy (ART) by sex. Brazil, 2008

\begin{tabular}{|c|c|c|c|c|c|c|}
\hline & \multicolumn{4}{|c|}{ Sex } & \multicolumn{2}{|c|}{ Total } \\
\hline & \multicolumn{2}{|c|}{ Male } & \multicolumn{2}{|c|}{ Female } & \multirow[b]{2}{*}{ n } & \multirow[b]{2}{*}{$\%$} \\
\hline & $n$ & $\%$ & $\mathrm{n}$ & $\%$ & & \\
\hline \multicolumn{7}{|l|}{ Age group (years) } \\
\hline $18-49$ & 578 & 79.2 & 406 & 78.8 & 984 & 79.0 \\
\hline $50+$ & 152 & 20.8 & 109 & 21.2 & 261 & 21.0 \\
\hline \multicolumn{7}{|l|}{ Skin color } \\
\hline White & 349 & 48.4 & 219 & 43.0 & 568 & 46.2 \\
\hline Black & 87 & 12.1 & 83 & 16.3 & 170 & 13.8 \\
\hline Brown & 281 & 39.0 & 199 & 39.1 & 480 & 39.0 \\
\hline Other & 4 & 0.6 & 8 & 1.6 & 12 & 1.0 \\
\hline \multicolumn{7}{|l|}{ Educational level } \\
\hline Incomplete fundamental school & 290 & 39.7 & 258 & 50.1 & 548 & 44.0 \\
\hline Fundamental school or higher & 440 & 60.3 & 257 & 49.9 & 697 & 56.0 \\
\hline \multicolumn{7}{|l|}{ Work status } \\
\hline Currently working & 328 & 44.9 & 196 & 38.1 & 524 & 42.1 \\
\hline Retired due to disease/disability & 284 & 38.9 & 133 & 25.8 & 417 & 33.5 \\
\hline Housewife/Family caring & - & - & 90 & 17.5 & 90 & 7.2 \\
\hline Does not work for other reason & 118 & 16.2 & 96 & 18.6 & 214 & 17.2 \\
\hline \multicolumn{7}{|l|}{ Monthly income } \\
\hline No income & 99 & 13.7 & 124 & 24.4 & 223 & 18.1 \\
\hline$<\mathrm{R} \$ 760.00$ & 323 & 44.7 & 302 & 59.4 & 625 & 50.8 \\
\hline$\geq \mathrm{R} \$ 760.00$ and $<\mathrm{R} \$ 2,000.00$ & 234 & 32.4 & 70 & 13.8 & 304 & 24.7 \\
\hline $\mathrm{R} \$ 2,000.00$ or more & 67 & 9.3 & 12 & 2.4 & 79 & 6.4 \\
\hline \multicolumn{7}{|l|}{ Economic class * } \\
\hline$A$ or $B$ & 175 & 24.0 & 72 & 14.0 & 247 & 19.8 \\
\hline C & 377 & 51.6 & 278 & 54.0 & 655 & 52.6 \\
\hline $\mathrm{D}$ or $\mathrm{E}$ & 178 & 24.4 & 165 & 32.0 & 343 & 27.6 \\
\hline Total (\% in row) & 730 & 58.6 & 515 & 41.4 & 1,245 & 100.0 \\
\hline
\end{tabular}

* Brazilian Economic Classification Criteria 23.

the proportion of women with counts of less than $200(12 \%)$ was significantly smaller than that of the men (21\%). More than $60 \%$ of the patients reported that they had some kind of side effect or adverse reaction to one of their antiretroviral medications, and $22 \%$ reported having lipodystrophy. Among those patients with lipodystrophy, $16 \%$ had received methacrylate implants (data not presented).

Data regarding different aspects of the selfrated health are presented in Table 3. Regarding the health status, $65 \%$ of patients evaluated their health status as excellent or good. Work capacity was better for women, although they felt worse about their physical appearance. An intense or very intense degree of difficulty in following treatment was reported by only $7.5 \%$ of patients (9\% for females and $6 \%$ for males).

Among other evaluated health status dimensions, $13 \%$ reported an intense or very intense degree of difficulty in performing routine activities. A similar situation was found regarding the degree of difficulty for locomotion (12\%), personal relationships (12\%) and the degree of difficulty associated to concentration/memory (10\%). A remarkably high proportion of the women reported intense or extreme pain or discomfort (33\%), sadness or depression (33\%), and worry or anxiety (47\%). Among the men, these proportions were also quite high, $21 \%, 23 \%$, and $34 \%$, respectively (Table 3).

Table 4 shows the proportions of patients with excellent or good self-rated health according to the patients' characteristics, as well as the significance levels for the associations of these variables with self-rated health. All the analyzed social-demographic characteristics, except sex and age were individually associated to the health status. The variables used to measure the socioeconomic status (education, income and 
Clinical and treatment-related characteristics of patients receiving antiretroviral therapy (ART) by sex. Brazil, 2008

\begin{tabular}{|c|c|c|c|c|c|c|}
\hline & \multicolumn{4}{|c|}{ Sex } & \multicolumn{2}{|c|}{ Total } \\
\hline & \multicolumn{2}{|c|}{ Male } & \multicolumn{2}{|c|}{ Female } & \multirow[b]{2}{*}{$\mathrm{n}$} & \multirow[b]{2}{*}{$\%$} \\
\hline & $\mathrm{n}$ & $\%$ & $\mathrm{n}$ & $\%$ & & \\
\hline \multicolumn{7}{|l|}{ ART starting year } \\
\hline$<1996$ & 43 & 6.3 & 22 & 4.6 & 65 & 5.6 \\
\hline 1996-1999 & 148 & 21.7 & 102 & 21.3 & 250 & 21.5 \\
\hline $2000-2003$ & 196 & 28.8 & 144 & 30.0 & 340 & 29.3 \\
\hline $2004-2006$ & 162 & 23.8 & 125 & 26.0 & 287 & 24.7 \\
\hline $2007+$ & 132 & 19.4 & 87 & 18.1 & 219 & 18.9 \\
\hline \multicolumn{7}{|l|}{ Last count of $\mathrm{CD} 4+$} \\
\hline$<200$ cells $/ \mathrm{mm}^{3}$ & 80 & 21.3 & 29 & 12.4 & 109 & 17.9 \\
\hline 200-349 cells $/ \mathrm{mm}^{3}$ & 73 & 19.4 & 41 & 17.6 & 114 & 18.7 \\
\hline 350 cells $/ \mathrm{mm}^{3}$ or more & 223 & 59.3 & 163 & 70.0 & 386 & 63.4 \\
\hline \multicolumn{7}{|l|}{ Exposure category } \\
\hline MSM & 254 & 38.2 & 0 & 0.0 & 254 & 22.1 \\
\hline Heterosexual & 314 & 47.2 & 445 & 92.3 & 759 & 66.2 \\
\hline IDU & 53 & 8.0 & 7 & 1.5 & 60 & 5.2 \\
\hline Blood & 20 & 3.0 & 17 & 3.5 & 37 & 3.2 \\
\hline Other & 24 & 3.6 & 13 & 2.7 & 37 & 3.2 \\
\hline \multicolumn{7}{|l|}{ Side/Adverse effects } \\
\hline No & 291 & 41.4 & 160 & 32.3 & 451 & 37.6 \\
\hline Yes, excluding lipodystrophy & 262 & 37.3 & 226 & 45.6 & 488 & 40.7 \\
\hline Yes, including lipodystrophy & 150 & 21.3 & 110 & 22.2 & 260 & 21.7 \\
\hline \multicolumn{7}{|l|}{ Presence of symptoms } \\
\hline Yes & 422 & 59.4 & 266 & 52.0 & 688 & 56.3 \\
\hline No & 288 & 40.6 & 246 & 48.0 & 534 & 43.7 \\
\hline
\end{tabular}

IDU: injecting drug users; MSM: men who have sex with men.

economic class) were strongly associated with health status, as higher the SES the better the self-evaluation of health status.

Regarding patient characteristics, low CD4+ counts, the occurrence of AIDS-related symptoms, reporting of side or adverse effects were associated with a poor self-rated health (Table 4).

Results of multivariate logistic regression models to investigate which of the variables were mostly associated to excellent or good selfrated health are presented in Table 5. Regarding the variables remaining in the stepwise model, "having completed fundamental school" (OR = 1.70) and "belonging to economic classes A or B" (OR $=2.36$ ) were positively associated with better evaluation of the health status. Moreover, "having been retired due to illness, unable to work or receiving disease benefits" ( $O R=0.46$ ), as well as "having reported effect and/or adverse effects" (OR $=0.57$ and $\mathrm{OR}=0.32$ respectively, with and without lipodystrophy), "occurrence of AIDS symptoms" (OR $=0.58)$ and "having started treatment after 2007 " (OR $=0.61)$ were associated with a poor evaluation of the health status.

\section{Discussion}

Results of the World Health Survey, a populationbased household survey carried out in Brazil in 2003, showed that $53 \%$ of the Brazilian population considered their health as good or excellent, varying from $47 \%$ among women to $60 \%$ among men 24 . In the current study, using the exact same question as was used in the World Health Survey for self-rated health, this proportion was $65 \%$ (64\% among women and $66 \%$ among men), that is, better than the evaluation of the general population, mainly among women. This result is surprising, considering that, according to World Health Survey-2003 data only $27 \%$ of persons with chronic or long-standing illness consider their health as good or excellent 25 .

One possible explanation for this finding lies in the improved quality of life of patients with 
Distribution of self-rated health and domains according to sex. Brazil, 2008.

\begin{tabular}{|c|c|c|c|c|c|c|c|c|c|}
\hline & \multicolumn{6}{|c|}{ Sex } & \multicolumn{3}{|c|}{ Total } \\
\hline & \multicolumn{3}{|c|}{ Male $(n=730)$} & \multicolumn{3}{|c|}{ Female $(n=515)$} & \multirow[b]{2}{*}{$\begin{array}{l}\text { Excellent/ } \\
\text { Good }\end{array}$} & \multirow[b]{2}{*}{ Moderate } & \multirow[b]{2}{*}{$\begin{array}{c}\text { Bad/Very } \\
\text { bad }\end{array}$} \\
\hline & $\begin{array}{l}\text { Excellent/ } \\
\text { Good }\end{array}$ & Moderate & $\begin{array}{c}\text { Bad/Nery } \\
\text { bad }\end{array}$ & $\begin{array}{l}\text { Excellent/ } \\
\text { Good }\end{array}$ & Moderate & $\begin{array}{c}\text { Bad/ } \\
\text { Very bad }\end{array}$ & & & \\
\hline Health & 66.4 & 26.4 & 7.1 & 63.9 & 26.0 & 10.1 & 65.4 & 26.3 & 8.4 \\
\hline Work capacity & 50.4 & 22.3 & 27.3 & 56.3 & 21.6 & 22.1 & 52.9 & 22.0 & 25.1 \\
\hline \multirow[t]{2}{*}{ Physical appearance } & 62.2 & 24.8 & 13.0 & 58.1 & 23.3 & 18.6 & 60.5 & 24.2 & 15.3 \\
\hline & $\begin{array}{l}\text { None/ } \\
\text { Slight }\end{array}$ & Moderate & $\begin{array}{c}\text { Intense/ } \\
\text { Very } \\
\text { intense }\end{array}$ & $\begin{array}{l}\text { None/ } \\
\text { Slight }\end{array}$ & Moderate & $\begin{array}{c}\text { Intense/ } \\
\text { Very } \\
\text { intense }\end{array}$ & Non/light & Moderate & $\begin{array}{c}\text { Intense/ } \\
\text { Very } \\
\text { intense }\end{array}$ \\
\hline $\begin{array}{l}\text { Difficulty in carrying out } \\
\text { day-to-day activities }\end{array}$ & 65.5 & 23.0 & 11.5 & 66.2 & 17.5 & 16.3 & 65.8 & 20.7 & 13.5 \\
\hline $\begin{array}{l}\text { Difficulty in adhering to } \\
\text { treatment }\end{array}$ & 83.6 & 10.3 & 6.2 & 79.8 & 10.9 & 9.3 & 82.0 & 10.5 & 7.5 \\
\hline Difficulty in locomotion & 77.9 & 11.9 & 10.1 & 74.2 & 11.1 & 14.8 & 76.4 & 11.6 & 12.0 \\
\hline Difficulty in physical activity * & 74.2 & 14.3 & 11.6 & 71.7 & 14.9 & 13.4 & 73.3 & 14.5 & 12.3 \\
\hline Difficulty with self-care & 92.5 & 6.2 & 1.4 & 88.9 & 8.3 & 2.7 & 91.0 & 7.1 & 1.9 \\
\hline $\begin{array}{l}\text { Difficulty relating to others and } \\
\text { community }\end{array}$ & 81.4 & 8.9 & 9.7 & 77.3 & 6.8 & 15.9 & 79.7 & 8.0 & 12.3 \\
\hline $\begin{array}{l}\text { Difficulty with concentration/ } \\
\text { memory }\end{array}$ & 72.9 & 18.6 & 8.5 & 64.5 & 22.9 & 12.6 & 69.4 & 20.4 & 10.2 \\
\hline Feelings of pain/discomfort & 61.2 & 17.4 & 21.4 & 48.5 & 18.4 & 33.0 & 56.0 & 17.8 & 26.2 \\
\hline Problems with sleeping & 62.6 & 13.8 & 23.6 & 56.9 & 14.6 & 28.5 & 60.2 & 14.1 & 25.6 \\
\hline $\begin{array}{l}\text { Tiredness on waking and } \\
\text { throughout the day }\end{array}$ & 61.1 & 19.7 & 19.2 & 56.7 & 17.9 & 25.4 & 59.3 & 19.0 & 21.8 \\
\hline $\begin{array}{l}\text { Feelings of sadness and } \\
\text { depression }\end{array}$ & 59.2 & 18.2 & 22.6 & 47.0 & 20.0 & 33.0 & 54.1 & 19.0 & 26.9 \\
\hline Feelings of worry and anxiety & 43.4 & 23.0 & 33.6 & 34.2 & 19.2 & 46.6 & 39.6 & 21.4 & 39.0 \\
\hline
\end{tabular}

* 281 male patients and 246 female patients did not perform physical activities and were not included in this analysis, being analyzed 449 and 269 patients respectively.

AIDS and the expectation of a long lifespan after the advent of HAART 15. This hypothesis is corroborated by the patient characteristics examined here, such as the positive association of good self-rated health with the absence of HIV-related symptoms and treatment-related side-effects. It was also seen that the lower a patient's CD4+ count, the worse their perception about their health. In addition, among patients aged 50 and over, $68.5 \%$ began treatment before 2003, showing the life-prolonging effect of the treatment.

For people diagnosed with HIV/AIDS, given the high lethality of the disease at the onset of the epidemic, it is important to consider the great impact on life perspectives at the moment of the diagnosis. After beginning treatment, however, improved immune function and well-being re- store a sense of hope for the future, as well as a positive perception about their health. This can be perceived in patients' responses such as: "Compared with what I've been through, now I'm great" or, "I thought I was going to die"; "Now I've discovered that there's nothing wrong with me", "I just have to take my medicines". Besides, the presence of the word "currently" in the general question on self-rated health may have contributed to the patients' comparison with their health at the time of diagnosis, and to review the various physical and psychological problems they have encountered since their diagnosis until the moment of the interview.

Another important factor to explain the high proportion of patients with good health selfevaluation has to do with the limitations of this type of study. The questionnaire was applied to 
Proportion and number of patients who rated their health as excellent or good according to patients' characteristics. Brazil, 2008

\begin{tabular}{|c|c|c|c|}
\hline & \multicolumn{3}{|c|}{ Self-evaluation of health as excellent or good } \\
\hline & $\mathrm{n}$ & $\%$ & p-value \\
\hline \multicolumn{4}{|l|}{ Sex } \\
\hline Male & 730 & 66.4 & 0.512 \\
\hline Female & 515 & 63.9 & \\
\hline \multicolumn{4}{|l|}{ Age (years) } \\
\hline $18-49$ & 984 & 65.4 & 0.937 \\
\hline $50+$ & 261 & 65.1 & \\
\hline \multicolumn{4}{|l|}{ Skin color } \\
\hline White & 568 & 67.1 & 0.002 * \\
\hline Black & 170 & 74.1 & \\
\hline Brown & 480 & 61.3 & \\
\hline Other & 12 & 50.0 & \\
\hline \multicolumn{4}{|l|}{ Educational level } \\
\hline Incomplete fundamental school & 548 & 56.8 & $<0.001$ \\
\hline Fundamental school or higher & 697 & 72.2 & \\
\hline \multicolumn{4}{|l|}{ Work situation } \\
\hline Currently working & 524 & 76.1 & $<0.001$ \\
\hline Retired due to disease/disability & 417 & 53.5 & \\
\hline Housewife/Family caring & 90 & 67.8 & \\
\hline Does not work for other reason & 214 & 61.2 & \\
\hline \multicolumn{4}{|l|}{ Monthly income } \\
\hline No income & 223 & 56.5 & $<0.001$ \\
\hline$<\mathrm{R} \$ 760.00$ & 625 & 62.4 & \\
\hline$\geq \mathrm{R} \$ 760.00$ and $<\mathrm{R} \$ 2,000.00$ & 304 & 73.7 & \\
\hline $\mathrm{R} \$ 2,000.00$ or more & 79 & 82.3 & \\
\hline \multicolumn{4}{|l|}{ Economic class ** } \\
\hline$A$ or $B$ & 247 & 77.3 & $<0.001$ \\
\hline C & 655 & 67.3 & \\
\hline $\mathrm{D}$ or $\mathrm{E}$ & 343 & 53.1 & \\
\hline \multicolumn{4}{|l|}{ ART starting year } \\
\hline$<2007$ & 942 & 66.0 & 0.079 \\
\hline $2007+$ & 219 & 59.8 & \\
\hline \multicolumn{4}{|l|}{ Last count of $\mathrm{CD} 4+$} \\
\hline$<200$ cells $/ \mathrm{mm}^{3}$ & 109 & 45.9 & $<0.001$ \\
\hline $200-349$ cells $/ \mathrm{mm}^{3}$ & 114 & 58.8 & \\
\hline 350 cells $/ \mathrm{mm}^{3}$ or more & 386 & 73.8 & \\
\hline \multicolumn{4}{|l|}{ Exposure category } \\
\hline MSM & 254 & 72.8 & 0.045 \\
\hline Heterosexual & 759 & 64.0 & \\
\hline IDU & 60 & 55.0 & \\
\hline Blood & 37 & 64.9 & \\
\hline Other & 37 & 75.7 & \\
\hline \multicolumn{4}{|l|}{ Side/Adverse effects } \\
\hline No & 451 & 74.7 & $<0.001$ \\
\hline Yes, excluding lipodystrophy & 488 & 64.3 & \\
\hline Yes, including lipodystrophy & 260 & 52.7 & \\
\hline
\end{tabular}

(continues) 
Self-evaluation of health as excellent or good

n

$\%$

p-value

Presence of symptoms

$\begin{array}{rccc}\text { Yes } & 688 & 58.7 & <0.001 \\ \text { No } & 534 & 74.9 & \\ \text { Total } & 1,245 & 65.4 & \end{array}$

ART: antiretroviral therapy; IDU: injecting drug; MSM: men who have sex with men.

* The category "other" was not included in the statistical test;

** Brazilian Economic Classification Criteria 23.

Table 5

Logistic regression model results using excellent or good self-rated health as response variable by sex. Brazil, 2008

\begin{tabular}{|c|c|c|c|}
\hline & OR & $95 \% \mathrm{Cl}$ & p-value \\
\hline \multicolumn{4}{|l|}{ Sex } \\
\hline Male & 1.09 & $0.78-1.53$ & 0.605 \\
\hline Female & 1.00 & - & - \\
\hline \multicolumn{4}{|l|}{ Educational level } \\
\hline Incomplete fundamental school & 1.00 & - & - \\
\hline Fundamental school or higher & 1.70 & $1.36-2.12$ & 0.000 \\
\hline \multicolumn{4}{|l|}{ Work situation } \\
\hline Currently working & 1.00 & - & - \\
\hline Retired due to disease/disability aid & 0.46 & $0.31-0.67$ & 0.000 \\
\hline Housewife/Family caring & 1.24 & $0.67-2.29$ & 0.486 \\
\hline Does not work for other reason & 0.73 & $0.45-1.19$ & 0.204 \\
\hline \multicolumn{4}{|l|}{ Economic class * } \\
\hline$A$ or $B$ & 2.36 & $1.45-3.84$ & 0.001 \\
\hline C & 1.40 & $0.97-2.01$ & 0.071 \\
\hline $\mathrm{D}$ or $\mathrm{E}$ & 1.00 & - & - \\
\hline \multicolumn{4}{|l|}{ Side/adverse effects } \\
\hline No & 1.00 & - & - \\
\hline Yes, excluding lipodystrophy & 0.57 & $0.42-0.77$ & 0.001 \\
\hline Yes, including lipodystrophy & 0.32 & $0.23-0.45$ & 0.000 \\
\hline \multicolumn{4}{|l|}{ Presence of symptoms } \\
\hline Yes & 0.58 & $0.46-0.73$ & 0.000 \\
\hline No & 1.00 & - & - \\
\hline \multicolumn{4}{|l|}{ ART starting year } \\
\hline$<2007$ & 1.00 & - & - \\
\hline $2007+$ & 0.61 & $0.46-0.81$ & 0.001 \\
\hline
\end{tabular}

ART: antiretroviral therapy; $95 \% \mathrm{Cl}: 95 \%$ confidence interval.

* Brazilian Economic Classification Criteria 23.

patients who show up at health services to pick up their antiviral medications, in other words, "healthy" patients. Patients who were hospitalized, bed-ridden or not able to pick up their medications were excluded. In addition, deceased pa- tients and those who were not under ART were equally excluded.

Still, despite the positive health self-evaluation on the part of patients on ART, intense feelings of sadness and depression or worry and 
anxiety were present in much greater proportions than in the general population 26 . The proportions of intense or extreme pain or discomfort, difficulty sleeping or no disposition during the day were also much higher than those in the general population 27 . These results indicate that, despite most patients' positive health selfevaluation, many of them still have not overcome the psychological traumas caused by diagnosis with HIV/AIDS. Among female patients, almost half claimed to feel intense or extreme worry or anxiety.

Inequalities in health self-perception by sex have been well documented in the international literature 28. As in the current study, women in general rank their health more poorly than do men. The main explanation for this lies in gender roles, in which women express pain and discomfort more easily than men 29,30.

Despite having worse health self-evaluations, especially for animus status related aspects, women had better immune function, measured by CD4+ counts, than did their male counterparts. Possibly due to widespread testing for HIV during prenatal care, women are diagnosed earlier than men and reach health services in better condition than men 31 .

The question about most recent CD4+ counts, however, was problematic. Initially, the interview was supposed to be performed after the medical appointment. However, the pilot study showed that the patients preferred taking part in the study during the waiting time for the medical appointment. We then decided that the interview should be conducted at any moment, either before or after the appointment. This meant that many of the patients did not yet have their test results, and only $49 \%$ were able to respond to this question. As a result, this information was excluded from the multivariate logistic analysis.

No distinction was made in this study between side effects and adverse drug reactions. With the exception of lipodystrophy, which was considered separately, any side effects or adverse drug reactions mentioned by patients were considered. These side effects were mentioned by great part of the sample and showed a negative association with good self-rated health, especially among women. According to a study carried out in Belo Horizonte, Brazil, side effects/adverse reactions were one of the main difficulties in adhere to treatment 32 .

The study results indicate a higher level of education among AIDS patients when compared to the Brazilian population as a whole. Nonetheless, despite better education, the pattern of wealth distribution is similar. According to the National
Household Sample Survey (PNAD-2006) 34, about $67 \%$ of the Brazilian population over 18 years old has a monthly income of less than twice the minimum wage (including all income sources). Among AIDS patients, the proportion was similar, $69 \%$. However, when we compare the level of schooling of those receiving less than 2 minimum wages, in the general population, $30 \%$ have less than 3 years of schooling, while among patients in the same income group only $18 \%$ have less than 3 years of schooling. Results also show that the proportion of male patients who are unemployed (55\%) is much higher than among the general male population (21\%) 33 .

When socioeconomic status is analyzed together with self-rated health, there is a clear association between socioeconomic variables and health status perception. As with the Brazilian population as a whole $24,34,35$, self-rated health among AIDS patients is poorer as the worse is the socioeconomic status. These findings are also consistent with studies carried out in developed countries 5,36,37.

Among the indicators of socioeconomic status, educational level has probably been the most utilized one, since it is a stable attribute in adult life, different from the occupational and income status that may vary over time 36 , as in the case of AIDS patients. In fact, schooling was an important predictor of a positive health selfevaluation. Economic class, measured by household goods and education level of the head of household, was another major contributor to a satisfactory health self-perception. As discussed by Martikainen et al. 38, this indicator of wealthy reflects not just material needs, such as the ability to acquire good nutrition or housing, but is also a marker of social well-being. Being currently working was another important predictor of good self-rated health among patients.

In sum, a poor perception of one's own health can be seen as the result of suffering caused by the disease in interaction with social, cultural, psychological and environmental factors that modify the way in which a person is affected by the experienced problem. In the case of AIDS patients, although material well-being and educational level are relevant dimensions, ART seems to have a huge influence on individuals' self-perceptions about health status. This indicates the need to invest even more to reduce the negative effects of treatment, and to continue to improve treatment adherence and quality of life of those infected with HIV. Problems related to animus status, involving worry and anxiety about the future are still barriers that must be overcome to improve quality of life of people living with HIV/AIDS. 


\section{Resumo}

Em 2008, um inquérito foi conduzido em uma amostra selecionada probabilisticamente de 1.245 pessoas infectadas pelo HIV em terapia antirretroviral no Brasil. No presente trabalho, foram investigadas associações da autoavaliação da saúde com sexo, faixa etária, nível socioeconômico e características do paciente. Para as análises multivariadas foram utilizados modelos de regressão logística, tendo como variável resposta a autoavaliação boa ou excelente. Os resultados mostram que 65\% autoavaliaram sua saúde como excelente ou boa, $81 \%$ relataram nenhuma ou pouca dificuldade em seguir o tratamento, porém, 34\% dos homens e 47\% das mulheres relataram grau intenso ou muito intenso de sentimento de preocupação ou ansiedade. Nível de escolaridade, situação de trabalho, ausência de efeitos colaterais e ausência de sintomas foram os principais fatores associados à boa percepção à saúde. Problemas no estado de ânimo, envolvendo preocupação e ansiedade com o futuro, não foram ainda superados e são barreiras a serem enfrentadas para a melhoria da qualidade de vida dos pacientes de AIDS.

Terapia Anti-Retroviral de Alta Atividade; HIV; AutoAvaliação; Afeto

\section{Contributors}

P. R. B. Souza Junior collaborated in all stages of development, both the survey and the article. C. L. Szwarcwald contributed in the development of the survey, data analysis, and discussion. E. A. Castilho collaborated in the contextualization, interpretation of results and discussion, and in the selection of bibliographic references.

\section{Acknowledgment}

This work was performed with the support of the United States Agency for International Development (USAID) and the Department of STD, AIDS and Viral Hepatitis of the Brazilian Ministry of Health.

\section{References}

1. Gold M, Franks P, Erickson P. Assessing the health of the nation. The predictive validity of a preference-based measure and self-rated health. Med Care 1996; 34:163-77.

2. Devlin N, Hansen P, Herbison P. Variations in selfreported health status: results from a New Zealand survey. N Z Med J 2000; 113:517-20.

3. Kind P, Dolan P, Gudex C, Williams A. Variations in population health status: results from a United Kingdom national questionnaire survey. BMJ 1998; 316:736-41.

4. Pikhart H, Bobak M, Siegrist J, Pajak A, Rywik S, Kyshegyi J, et al. Psychosocial work characteristics and self rated health in four post-communist countries. J Epidemiol Community Health 2001; 55:624-30.

5. Franks P, Gold MR, Fiscella K. Sociodemographics, self-rated health, and mortality in the US. Soc Sci Med 2003; 56:2505-14.
6. Hunt SM, McKenna SP, McEwen J, Backett EM, Williams J, Papp E. A quantitative approach to perceived health status: a validation study. J Epidemiol Community Health 1980; 34:281-6.

7. Mossey JM, Shapiro E. Self-rated health: a predictor of mortality among the elderly. Am J Public Health 1982; 72:800-8.

8. Idler EL, Benyamini Y. Self-rated health and mortality: a review of twenty-seven community studies. J Health Soc Behav 1997; 38:21-37.

9. Kaplan GA, Camacho T. Perceived health and mortality: a nine-year follow-up of the human population laboratory cohort. Am J Epidemiol 1983; 117:292-304.

10. Burstrom B, Fredlund P. Self rated health: is it as good a predictor of subsequent mortality among adults in lower as well as in higher social classes? J Epidemiol Community Health 2001; 55:836-40. 
11. Blank N, Diderichsen F. The prediction of different experiences of longterm illness: a longitudinal approach in Sweden. J Epidemiol Community Health 1996; 50:156-61.

12. Bartlett JG, Gallant JE. Tratamento clínico da infecção pelo HIV. Baltimore: Johns Hopkins University; 2002.

13. Russell J, Krantz S, Neville S. The patient-provider relationship and adherence to highly active antiretroviral therapy. J Assoc Nurses AIDS Care 2004; 15:40-7.

14. Levi GC, Vitória MA. Fighting against AIDS: the Brazilian experience. AIDS 2002; 16:2373-83.

15. Marins JR, Jamal LF, Chen SY, Barros MB, Hudes ES, Barbosa AA, et al. Dramatic improvement in survival among adult Brazilian AIDS patients. AIDS 2003; 17:1675-82.

16. Chequer P, Hearst N, Hudes ES, Castilho E, Rutherford G, Loures L, et al. Determinants of survival in adult Brazilian AIDS patients, 1982-1989. The Brazilian State AIDS Program Co-Ordinators. AIDS 1992; 6:483-7.

17. Guibu IA, Barros MBA, Cordeiro MRD, Tayra A, Alves MCGP, Pereira GFM. Estudo de sobrevida de pacientes de AIDS no Brasil, 1998 a 1999" - fase I - Regiões Sul e Sudeste. Boletim Epidemiológico AIDST 2008; V:31-3.

18. Pitts M, Grierson J, Misson S. Growing older with HIV: a study of health, social and economic circumstances for people living with HIV in Australia over the age of 50 years. AIDS Patient Care STDS $2005 ; 19: 460-5$.

19. Szwarcwald CL, Viacava F. Pesquisa Mundial de Saúde no Brasil, 2003. Cad Saúde Pública 2005; 21 Suppl 1:S4-5.

20. Szwarcwald CL, Viacava F. Pesquisa Mundial de Saúde: aspectos metodológicos e articulação com a Organização Mundial da Saúde. Rev Bras Epidemiol 2008; 11 Suppl 1:58-66.

21. WHOQOLHIVGroup. WHOQOL-HIV for quality of life assessment among people living with HIV and AIDS: results from the field test. AIDS Care 2004; 16:882-9.

22. Zimpel RR, Fleck MP. Quality of life in HIV-positive Brazilians: application and validation of the WHOQOL-HIV, Brazilian version. AIDS Care 2007; 19:923-30.

23. Associação Brasileira de Empresas de Pesquisa. Critério de classificação econômica Brasil. São Paulo: Associação Brasileira de Empresas de Pesquisa; 2008.

24. Szwarcwald CL, Souza Junior PR, Esteves MA, Damacena GN, Viacava F. Socio-demographic determinants of self-rated health in Brazil. Cad Saúde Pública 2005; 21 Suppl 1:S54-64.

25. Theme-Filha MM, Szwarcwald CL, Souza Junior PR. Socio-demographic characteristics, treatment coverage, and self-rated health of individuals who reported six chronic diseases in Brazil, 2003. Cad Saúde Pública 2005; 21 Suppl 1:S43-53.
26. Szwarcwald CL, Bastos FI, Esteves MA. State of animus among Brazilians: influence of socioeconomic context? Cad Saúde Pública 2005; 21 Suppl 1:S33-42.

27. Szwarcwald CL, Viacava F, Vasconcellos MTL, Leal MC, Azevedo LO, Queiroz RSB, et al. Pesquisa Mundial de Saúde - 2003: o Brasil em números. Radis 2004; 23:14-33.

28. Denton M, Prus S, Walters V. Gender differences in health: a Canadian study of the psychological, structural and behavioral determinants of health. Soc Sci Med 2004; 58:2585-600.

29. Verbrugge LM. Sex differentials in health. Public Health Rep 1982; 97:417-37.

30. Gijsbers van Wijk CM, van Vliet KP, Kolk AM, Everaerd WT. Symptom sensitivity and sex differences in physical morbidity: a review of health surveys in the United States and The Netherlands. Women Health 1991; 17:91-124.

31. Souza Jr. PR, Szwarcwald CL, Castilho EA. Delay in introducing antiretroviral therapy in patients infected by HIV in Brazil, 2003-2006. Clinics 2007; 62:579-84.

32. Guimarães MD, Rocha GM, Campos LN, Freitas FM, Gualberto FA, Teixeira RA, et al. Difficulties reported by hiv-infected patients using antiretroviral therapy in Brazil. Clinics 2008; 63:165-72.

33. Instituto Brasileiro de Geografia e Estatística. Pesquisa Nacional por Amostra de Domicílios (PNAD). Rio de Janeiro: Instituto Brasileiro de Geografia e Estatística; 2006.

34. Lima-Costa MF, Barreto S, Giatti L, Uchoa E. Desigualdade social e saúde entre idosos brasileiros: um estudo baseado na Pesquisa Nacional por Amostra de Domicílios. Cad Saúde Pública 2003; 19:745-57.

35. Dachs JNW. Determinantes das desigualdades na auto-avaliação do estudo de saúde no Brasil: análise dos dados da PNAD/1998. Ciênc Saúde Coletiva 2002; 7:641-57.

36. Heistaro S, Vartiainen E, Puska P. Trends in selfrated health in Finland 1972-1992. Prev Med 1996; 25:625-32.

37. Mackenbach JP, Kunst AE, Cavelaars AEJM, Gronhof F, Geurts JJM. Socioeconomic inequalities in morbidity and mortality in Western Europe. The EU Working Group on Socioeconomic Inequalities in Health. Lancet 1997; 349:1655-9.

38. Martikainen P, Adda J, Ferrie JE, Smith GD, Marmot M. Effects of income and health on GHQ depression and poor self rated health in white collar women and men in the Whitehall II study. J Epidemiol Community Health 2003; 57:718-23.

Submitted on 01/Nov/2009

Final version resubmitted on 19/Mar/2010

Approved on 05/Apr/2010 